\title{
Structure and Use of Labour Resources in the Kaliningrad Region
}

\author{
Andrey P. Klemeshev \\ Immanuel Kant Baltic Federal University, Russian Federation \\ Corresponding Email: AKlemeshev@kantiana.ru
}

Doi:10.5901/mjss.2015.v6n6s7p129

\begin{abstract}
Labour resources of the Kaliningrad region are being raised in conditions of decreased reproduction against a significant influx of migrants from other Russian regions and the CIS countries. Involvement of labour resources is high, unemployment is low, though the latter slightly increased in the mid-2015 compared to 2014. Since 1990, the labour forces employed in the services sector have been redistributed between types of economic activities. Economic development strategy should be based on the growth of labour productivity and inter-sectoral reallocation of jobs rather than the increase in the number of jobs.
\end{abstract}

Keywords: Kaliningrad region, labour resources, balance of labour resources, employment

\section{Introduction}

Growth and use of labor resources are known to be defined by the combined action of two factors: the specificity of human reproduction and human resources, on the one hand, and the needs of the economy in the labor force, on the other. In the Kaliningrad region in the 2000s, both were more favorable than the average in Russia. The increased share of the able-bodied population in the population age structure and migration flow until 2008 encouraged a slightly expanded reproduction of the labor force, and later the workforce was shrinking slower than in most regions of the Russian Federation. The dynamic development of the region's economy in the 2000s provided for the increase in the number of jobs until 2009, and for only a small reduction and stabilization later. However, labor resources the proper amount and quality do not grow smoothly, and within the coming several the problem of labor supply and demand will become more urgent (Fedorov, 2014; Gimbitskiy et al., 2014; 2015). In the frames of this article we will make a survey of the features of the dynamics and the balance of labor resources growth in the Kaliningrad region in the 2000s. and their distribution for economic activities.

\section{Dynamics of the Labor Resources Balance}

In 1990 the economically active population of the Kaliningrad region remained virtually stable, while the number of employed in the economy, due to the economic crisis caused by the collapse of the Soviet Union and the difficulties of the transition from a command to a market economy, declined (Table 1). In 2000 - 2013 both figures increased, but the latter one showed a higher progress due to the creation of new jobs in the rapidly growing economies of the region.

Table 1. The dynamics of the economically active population and employment in the economy of the Kaliningrad region

\begin{tabular}{lcccccc}
\hline Indicators & 1990 & 1995 & 2000 & 2005 & 2010 & 2013 \\
\hline Economically active population & $493^{*}$ & 491 & 489 & 517 & 511 & 527 \\
Average annual number of employed in the economy & 436 & 392 & 410 & 447 & 471 & 476 \\
The ratio of employed to the economically active population, $\%$ & 88.4 & 79.8 & 83.8 & 86.5 & 92.2 & 90.3 \\
\hline Note: ${ }^{* 1992}$ & & & & &
\end{tabular}

Source: Complied by the author on: (Goskomstat, 2002; Rosstat, 2014).

According to the balance of labor resources, in 2013 the labor force in the Kaliningrad region amounted to 641.8 thousand people, an increase compared with 28.3 thousand in 2000 (Table. 2). In the early 2000s the labor force was increasing steadily until 2008, when it amounted to 651.5 thousand people. Then the number of labor force began to decline with a change in the population age structure, namely the influx of less numerous groups of those who were born in 1990s into the working age groups and quick exit of retired more numerous cohorts born after 1945. 
Table 2. The distribution of labour resources of the Kaliningrad region on the integrated groups of balance of labour resources

\begin{tabular}{lc}
\hline Indicators & $2000 \quad 2005 \quad 20102013$ \\
\hline $\begin{array}{l}\text { Labour resources - Total } \\
\text { Including: }\end{array}$ & 613.5644 .8636 .1641 .8 \\
$\begin{array}{l}\text { Employed population } \\
\text { Students of the able-bodies age, studying full-time }\end{array}$ & $\begin{array}{c}410.0446 .8 \\
\text { The able-bodied population of working age not employed in the economy of the region: the }\end{array}$ \\
$\begin{array}{l}40.042 .6 \quad 40.9 \\
\text { military, the Russian citizens working abroad, the unemployed, homemakers and others. }\end{array}$ & 163.5155 .4123 .8127 .5 \\
\hline
\end{tabular}

Source: Complied by the author on: Kaliningradstat (2001; 2006; 2011; 2014a).

Average number of employed in the economy from 2000 to 2013 increased from 410 thousand people to 476.5 thousand people or by $16 \%$. The maximum involvment was reached in 2009 - 485 thousand people. In 2010 - 2011 the number of employed declined under the influence of the global economic crisis, but in 2012 - 2013 it increased again, reaching, however, the level of 2009.

The number of able-bodied people in the workingng age labor force has been decreasing in recent years, however, the number of people older than working age involved in labor activities has grown almost 1.5 times, up to 58 thousand people.

During 2003 - 2013 the number of foreign migrant workers employed in the economy grew from 2 thousand to 17 thousand people. However, a significant number of the regionally registered Russian citizens work abroad (in 2008 their number was equal to 8 thousand people).

The number of students of working age, which amounted in 2000 to 40 thousand people increased to 44.9 thousand by 2002. Then, following the dynamics of the age structure of the population it began decreasing and in 2013 it amounted to 37.8 thousand people.

The number of Russian citizens working abroad, soldiers, housewives and the unemployed of working-age reduced by 36 thousand people or $28 \%$. According to experts, such a substantial change in the recorded statistics is largely attributed to the fact that a part of economy was no longer a "shadow" one. Another important factor was the rapid growth of the Kaliningrad economy in this period, which resulted in creating a significant number of new jobs.

The measures taken to stabilize the situation in the labour market gradually brought some results. By 2014, unemployment fell twice and accounted for $5.8 \%$, registered unemployment was the lowest since the early 2000 s, it comprised $1.2 \%$ of the economically active population. But in 2015 the situation began to deteriorate. Compared to the same period of the previous year, at the end of June 2015 the number of employed and unemployed people registered in the employment offices increased by 22\%, amounting to 7.2 thousand. (Kaliningradstat, 2015).

\section{The Structure of Employment by Types of Economic Activity}

The year 1990 witnessed de-industrialization of the region and a sharp reduction in the production of goods in other sectors of the economy. During 1990 - 1998 employment in production, i.e. industry, agriculture and forestry, construction, fell by almost a half (Table. 3). But employment in the service sector increased by half (more than twice in trade). The total number of employed in the economy decreased (according to experts, largely due to the transition of the workers to the 'shadow' sector of economy) (Samsom, 1998).

Table 3. The number of employed in some sectors of the economy of the Kaliningrad region, in thousand pers.

\begin{tabular}{lccc}
\hline Sector of the economy & 1990 & 1998 & 2013 \\
\hline Employed in the economy, total & 435 & 400 & 476 \\
Including & & & \\
Industry & 136 & 74 & 101 \\
Agriculture and forestry & 58 & 42 & 34 \\
Construction & 33 & 27 & 40 \\
Transport and communications & 38 & 31 & 44 \\
Other sectors & 170 & 257 & 257 \\
\hline
\end{tabular}

Source: (Kaliningradstat, 2014a; Oblstat, 1994). 
In 2000 - 2013, there were significant changes not only in numbers but also in the structure of employment in various economic activities (Table 4).

Table 4. Distribution of employees by economic activities, the Kaliningrad region, 2000 - 2013, in thousand people

\begin{tabular}{lcccc}
\hline & 2000 & 2005 & 2010 & 2013 \\
\hline Total & 413.2 & 446.8 & 471.4 & 476.5 \\
\hline including: & & & & \\
\hline Agriculture. hunting and forestry & 43.3 & 44.8 & 35.4 & 33.7 \\
Fishing and fishery & 3.9 & 3.8 & 3.8 & 4.3 \\
Natural resources extraction & 3.2 & 5.9 & 3.8 & 4.4 \\
Processing industries & 66.9 & 69.9 & 87.1 & 84.6 \\
Production and distribution of electricity. gas and water & 10.2 & 10.3 & 10.9 & 12.2 \\
Construction & 24.6 & 32.6 & 35.7 & 39.9 \\
Wholesale and retail trade. servicing vehicles. household gadgets. and personal use items & 73.3 & 74.0 & 79.7 & 81.0 \\
Hotels and restaurants & 6.7 & 9.6 & 9.7 & 10.7 \\
Transport and communications & 32.2 & 45.0 & 40.9 & 44.3 \\
Financial activities & 4.7 & 5.6 & 7.6 & 7.4 \\
Real property operations. rent and services & 25.9 & 31.2 & 38.3 & 38.1 \\
Public administration. military security. compulsory social security & 32.5 & 34.8 & 40.5 & 37.0 \\
Education & 35.2 & 35.6 & 32.3 & 31.8 \\
Healthcare and social services & 31.6 & 25.8 & 26.3 & 28.1 \\
Other utility. social and personal services & 19.0 & 17.9 & 19.4 & 19.0 \\
\hline
\end{tabular}

Source: Kaliningradstat, 2002; 2006; 2014b.

The number of people employed in the agricultural sector reduced significantly, by $28 \%$. The number of those employed in education and health also decreased. In the manufacturing industry, which has been operating since 2006 and exercising two types of benefits - customs benefits (under the law on special economic zone in 1996) and tax benefits (according to the Law on the SEZ in 2006), the number of employees increased by 26\%. A significant increase in the number of employees was seen in the construction, trade, transport and communications, hotels and restaurants. Employment grew in the sector of finance, operations with real estate, renting and business services, public administration and defence, social security.

Large structural changes occurred in employment within some certain types of economic sectors, especially in the industry. The former sectors of the industry specialization, developed in 1990, like fishing, machinery engineering, pulp and paper production lost their leading role. The main role was shifted to motor vehicles assembly and food processing, mainly from imported raw materials.

A certain role in the economy of the region belongs to the informal sector. The situation in the Kaliningrad region changed significantly in the 2000s, compared to the 1990s when the informal sector was highly developed. According to a survey on population employment in 2014, the employment in the Kaliningrad region is marked by close to the average in Russia rather than higher share of employment in the informal sector. In the Kaliningrad region, the share is $20.1 \%$, while in Russia as a whole - $20.6 \%$ (Kaliningradstat, 2014c). Note that according to the survey methodology, those who are employed in the informal sector are the people who, during the reference period were engaged in at least one of the production units of the informal sector, regardless of their employment status and of whether they considered this work as primary or secondary. The criterion of the absence of state registration as a legal entity is chosen as a criterion for determining the units of the informal sector.

\section{Conclusion}

Changes in labour force reproduction, growth of economically active population and shaping the sectoral structure of employment requires a corresponding adjustment in the professional training of workers and specialists. There are large disproportions here: there is a certain gap in training skilled workers and technicians, bachelors, particularly in humanities, outnumber other specialists. A solutions to the problem is in university transition to training bachelors in applied sciences who obtain both a higher education and a vocational degree. Creating a balanced system of three interacting units - "the economy - human resources - the education system" is the most important task in the coming 
years to be solved in the Kaliningrad region and in the Russian Federation.

At the same time there is a task of ensuring a balance between the rate of reproduction of the labour force and the creation of new jobs in the economy. Economic restructuring should lead to the creation of high-performance jobs, the development of innovative industries that rely on scientific and technological potential of the region (in particular the I. Kant Baltic Federal University as well as other universities and research organizations). The development of new industries should be based primarily on the retraining of workers who were made redundant while different types of economic activities were being modernized. The factor to rely on is not a significant influx of migrants (often unskilled) from the outside, but rather the productivity of labour as a source of economic development.

\section{References}

Fedorov, G.M. (2015). Efficient labor resources as a development factor in the Kaliningrad region. Baltic Region, 1(23), 101-116.

Gimbitskiy, K.K., Kuznetsova, A.L., \& Fedorov, G.M. (2014). The development of the economy of the Kaliningrad region: stages of restructuring. Baltic Region, 1(19), 56-71.

Gimbitskiy, K.K., Voloshenko, K.Yu., Kuznetsova, A.L., \& Fedorov, G.M. (2015). Modelling the regional system of a long-term sustainability of the Kaliningrad region. Kaliningrad: IKBFU.

Goskomstat (2002). Regions of Russia: Social and economic indicators. Moscow, 2014.

Kaliningradstat (2001). The balance of labor resources in 2000 in the Kaliningrad region. Kaliningrad.

Kaliningradstat (2002). The Kaliningrad region in figures: 2002. Kaliningrad.

Kaliningradstat (2006). The balance of labor resources in 2005 in the Kaliningrad region. Kaliningrad.

Kaliningradstat (2006). The Kaliningrad region in figures: 2006. Kaliningrad.

Kaliningradstat (2011). The balance of labor resources in 2010 in the Kaliningrad region. Kaliningrad.

Kaliningradstat (2014a). The balance of labor resources in 2013 in the Kaliningrad region. Kaliningrad.

Kaliningradstat (2014b). The Kaliningrad region in figures: 2014. Kaliningrad.

Kaliningradstat (2014c). Study of the population employment - 2014 figures. [Online] Available: http://www.gks.ru/bgd/regl/b14_30/ Main.htm (December 19, 2014).

Kaliningradstat (2015). Social and economic situation in the 1 quarter of 2015 in the Kaliningrad region. Kaliningrad.

Oblstat (1994). The Amber island of Russia. Kaliningrad.

Rosstat (2014). Regions of Russia: Social and economic indicators. Moscow.

Samson, I. (1998). Kaliningrad region: The diagnosis of a crisis. University Pierre Mendes France, Grenoble. 